\title{
INITIATION OF URATE LOWERING THERAPY (ULT)
}

Dr Richard Lee Meng Kam and Dr Anita Lim Yee Nah

\section{Abstract / Background:}

Mr Tan, 60, a smoker with diabetes mellitus (DM), hypertension and chronic kidney disease (CKD) Stage 3, and recurrent gout flares last five weeks of increasing intensity and duration. He assumes it is due to frequent travel and lack of exercise. He comes today for routine review of his chronic diseases. Current laboratory results are creatinine 106, eGFR 56, uric acid 490, HbA1c 7.3\%, random hypocount 8.5 $\mathrm{mmol} / \mathrm{L}$. He is on glipizide $5 \mathrm{mg}$ bd, Metformin $250 \mathrm{mg}$ BD, Amlodipine 5mg OM. He complains of severe gout pain. He had always been reluctant to start definitive treatment which you had previously mentioned. What will you do next?

\section{Keywords: ULT; prophylaxis; colchicine; treatment targets}

\section{Indications for starting Urate Lowering Therapy (ULT)}

ULT should be considered and discussed with every patient with a definite diagnosis of gout. ULT is indicated in patients with recurrent flare ( $\geq 2$ times/year), tophi, urate arthropathy and/or renal stones. ${ }^{1}$

Patients with gout should be counselled and involved in decisionmaking concerning the use of ULT.

ULT allows for dissolution of crystal deposits and the disappearance of gout features, provided that uric acid levels are treated to target. Effective ULT reduces the size and number of tophiand facilitates their disappearance, thereby improving quality of life, which can be seriously impaired., ${ }^{2,3}$

\section{Timing of initiation of ULT}

Should urate-lowering drugs be initiated during a flare or wait until a fortnight later? Two small trials suggest that allopurinol initiation during an acute gout attack did not prolong the duration of flares nor worsen its severity as compared with delayed initiation. Early treatment in patients with comorbidities is supported by a study of a large cohort of gout patients in whom hypertension, ischaemic heart disease and CKD were associated with increased risk of recurrence of flare. ${ }^{4}$

\section{DR RICHARD LEE MENG KAM}

Family Physician, Consultant

Assistant Director, Family Medicine Development

National Healthcare Group Polyclinics

\section{DR ANITA LIM YEE NAH}

Senior Consultant, Division of Rheumatology

University Medicine Cluster

National University Hospital
There is a need to start ULT early, particularly in patients with comorbidities and/or Serum Uric Acid (SUA) level >8mg/dL(476 umol/L).Support to treat patients with high SUA level earlier is based on studies showing an association of hyperuricaemia with increased flare frequency.

\section{Treatment targets for ULT}

For patients on ULT, the SUA level should be monitored, treated to $<6 \mathrm{mg} / \mathrm{dL}$ ( $360 \mathrm{umol} / \mathrm{L}$ ) and maintained. The exceptions will be the elderly with limited life expectancy or when the patient has indicated a preference not to treat to target SUA and only to symptom control.

A lower SUA target $(<5 \mathrm{mg} / \mathrm{dL} ; 300 \mathrm{umol} / \mathrm{L})$ is recommended for patients with tophaceous gout.

ULT should be stopped when SUA level $<3 \mathrm{mg} / \mathrm{dL}(174 \mathrm{umol} / \mathrm{L})$ as this is not recommended in the long term.

Some studies suggest that uric acid might protect against various neurodegenerative diseases such as Parkinson's disease, Alzheimer's disease and amyotrophic lateral sclerosis., 6

\section{How to initiate:}

Types of ULT:

\section{Xanthine oxidase inhibitors: XOI}

-Allopurinol (1st line)

-Febuxostat is a potent non purine selective xanthine oxidase inhibitor, which is metabolised in the liver and not excreted via the kidneys. Therefore, it can be considered for use inpatients with allopurinol allergy or moderate to severe renal impairment. Normal daily dose of febuxostat is $80 \mathrm{mg}$.

Risk factors of allopurinol inducedserious cutaneous adverse reactions(SCAR) include the presence of HLA-B $^{\star} 5801$ allele, starting dose of allopurinol and renal impairment. The frequency of $\mathrm{HLA}^{*} \mathrm{~B}^{\star} 5801$ prevalence is estimated at 18.5 percent in Singapore; 1 in 5 Chinese, 1 in 15 Malays and 1 in 25 Indians. HLA-B ${ }^{\star} 5801$ genotyping is available in Singapore but is not mandatory in patients starting allopurinol. It is important to bear in mind that this test needs to be interpreted correctly. Among 100 allopurinol users with positive HLA-B ${ }^{\star} 5801$, only two patients may develop serious cutaneous adverse reactions (SCAR) while among 100 patients who test negative, almost all are not at risk of developing allopurinol-induced SCAR. Therefore, the test may deny many people who will not have developed SCAR from allopurinol,a cheap and effective means to lower uric acid. 


\section{Uricosuric agents}

- Probenecid (1-2 g/day) - Do not use in patients with renal stones or renal impairment (Creatinine clearance $<30 \mathrm{ml} / \mathrm{min}$ )

- Benzbromarone (50-200 mg/day) - this is not commonly used in the primary care setting.

Allopurinol should be started at a low dose (100 mg/day) even in patients with normal kidney function to reduce the likelihood of an early gout flare. A high starting dose increases the risk of SCAR. ${ }^{7,8}$ Optimal dose of allopurinol $300 \mathrm{mg} /$ day achieves the SUA target of $6 \mathrm{mg} / \mathrm{dL}(360 \mathrm{umol} / \mathrm{L})$ in about $70-80$ percent of patients.

Treatment with allopurinol can be titrated up to $600-800 \mathrm{mg} /$ day. Compliance must be ascertained prior to escalating doses.

A review for side effects is recommended in 4-6 weeks with slow upward titration of ULT in every patient.

Allopurinol may be combined with a uricosuricagent if target SUA cannot be attained in the presence of continued flares. Febuxostat or a uricosuric agent is indicated if allopurinol cannot be tolerated.

In patients with renal impairment, allopurinol should start low at $50 \mathrm{mg}$ OM. Titration of the dose should be much slower to achieve and maintain the same target SUA as in patients with normal renal function.

Renal failure is associated with an increased risk of SCARs and poor outcome. Decreased renal function results in decreased clearance and higher serum levels of oxypurinol, which can induce a cytotoxic T-cell response and trigger hypersensitivity reactions in SCARs.

Febuxostat has been found to be more effective in patients with CKD than allopurinol given at doses adjusted to creatinine clearance. Febuxostat should be avoided in or used with particular caution in patients with high cardiovascular risk.

Prophylaxis with colchicine is recommended during the first 6 months of ULT.

Recommended prophylaxisis colchicine, $0.5-1 \mathrm{mg} / \mathrm{day}$, in which the dose should be reduced in patients with renal impairment. Clinicians should be aware of potential neurotoxicity and/ or muscular toxicity with prophylactic colchicine in renal impairment or statin treatment. Co-prescription of colchicine with strong P-glycoprotein and/or CYP3A4 inhibitors should be avoided. If colchicine is not tolerated or is contraindicated, low dose prednisolone may be used but caution is needed in diabetics. Occasionally, as needed NSAIDs may be sufficient.

\section{$\underline{\text { Review of patient in 4-6 weeks: }}$}

Side effects from medications and break through gout flares should be monitored with full blood count (FBC), uric acid, alanine aminotransferase (ALT) and creatinine level (Table 1). Patient can be counselled by dietitian and nurse manager on lifestyle and diet.
Table 1: Side Effects of Allopurinol

\begin{tabular}{|c|c|c|}
\hline Side effects & Warning signs & $\begin{array}{c}\text { Things you need } \\
\text { to do }\end{array}$ \\
\hline $\begin{array}{l}\text { Allergic reaction, } \\
\text { especially skin } \\
\text { reactions (if it } \\
\text { occurs, it usually } \\
\text { starts within the } \\
\text { first few weeks to } \\
3 \text { months). }\end{array}$ & $\begin{array}{l}\text { Skin rashes, itching, } \\
\text { redness, burning } \\
\text { sensation. } \\
\text { Fever, sore throat, red eyes } \\
\text { or mouth sores may be } \\
\text { early symptoms }\end{array}$ & $\begin{array}{l}\text { Stop medication and see a } \\
\text { doctor immediately as this } \\
\text { may be a serious allergy. } \\
\text { If the rash is mild, your } \\
\text { doctor may re-introduce } \\
\text { Allopurinol at a lower dose } \\
\text { at another time. }\end{array}$ \\
\hline $\begin{array}{l}\text { Reduced blood } \\
\text { counts (rare) }\end{array}$ & $\begin{array}{l}\text { There may be no warning } \\
\text { signs but unusual bleeding } \\
\text { or bruising, lip or mouth } \\
\text { ulcers with flu-like } \\
\text { symptoms may occur }\end{array}$ & $\begin{array}{l}\text { Inform your doctor } \\
\text { immediately if these } \\
\text { symptoms occur. } \\
\text { Go for regular blood tests. }\end{array}$ \\
\hline $\begin{array}{l}\text { Liver } \\
\text { abnormalities }\end{array}$ & $\begin{array}{l}\text { Usually none, jaundice } \\
\text { may occur }\end{array}$ & Go for regular blood tests. \\
\hline \multicolumn{2}{|c|}{ Nausea, loss of appetite or diarrhoea } & $\begin{array}{l}\text { Take medication after food } \\
\text { or divide the dose into two to } \\
\text { be taken within the day }\end{array}$ \\
\hline
\end{tabular}

Clearly document counselling and monitoring for side effects.

1. Instruct ACTION PLAN if patient develops any of the above: a. Stop Allopurinol immediately. DO NOT take the next dose,

b. Stop taking medications (there is no need for permission from doctors)

c. Seek medical attention (A\&E) and inform any doctor of new drug, allopurinol (even if it was started in the past 3-4 months).

2. Explain the SEVERITY (What happens if drug is not stopped in time):

a. Allergic reaction can affect internal organs like liver, kidney and if reaction is severe, death can occur

3. End counselling on a reassuring note that you are accessible a. Call clinic if those symptoms occur, and inform patient you will provide close monitoring

\section{Common FAQs:}

\section{What if I missed a dose?}

If you missed a dose or forgot to take your medicine, take it as soon as you remember it.

If it is almost time for your next dose, skip the missed dose and continue with your regular schedule. Do not double the dosage to make up for the missed dose.

\section{Should I continue or stop taking Allopurinol during an acute gout attack?}

If you have been taking Allopurinol regularly, you should continue taking it during an acute gout attack, along with other medications to treat the acute gout attack.

\section{Can I drink alcohol while taking Allopurinol?}

Avoid or limit alcohol intake while on this medicine as alcohol can increase the amount of uric acid in your blood. Alcohol consumption can trigger acute gout attacks. 
4. Are there any medications to avoid while on Allopurinol? Allopurinol may increase the effects of warfarin, Azathioprine and Mercarptopurine, and may increase the incidence of skin rashes in patients taking Ampicillin.

\section{Acute treatment for Gout flares:}

An acute gout flare is an intensely painful and disabling inflammatory arthritis, usually involving a single joint, but occasionally involving two or more joints (Table 2).

Acute flares should be treated as early as possible. Fully informed patients can be taught to self-medicate at the first warning symptoms.

Choose $\operatorname{drug}(\mathrm{s})$ based on contraindications, the patient's previous experience with treatments, time of initiation after flare onset and the number and type of joint(s) involved.

Table 2: Gout Classification Criteria

\begin{tabular}{|c|c|c|}
\hline \multicolumn{2}{|c|}{ Criteria (2015 ACR-EULAR) ${ }^{9}$} & \multirow{2}{*}{$\begin{array}{l}\text { Categories } \\
\text { Please select the highest category } \\
\text { ever noted for each criteria. }\end{array}$} \\
\hline \multirow{12}{*}{ 胥 } & \multirow[t]{3}{*}{$\begin{array}{l}\text { Pattern of joint/ bursa } \\
\text { involvement during } \\
\text { symptomatic episode(s) ever }\end{array}$} & \\
\hline & & $\begin{array}{l}\text { Ankle or midfoot (as part of } \\
\text { monoarticular or oligoarticular episode } \\
\text { without 1st MTP involvement) }\end{array}$ \\
\hline & & $\begin{array}{l}\text { MTP (as part of monoarticular or } \\
\text { oligoarticular episode) }\end{array}$ \\
\hline & \multirow{4}{*}{$\begin{array}{l}\text { Characteristics of } \\
\text { symptomatic episode(s) ever: } \\
\text { (i) Erythema overlying } \\
\text { affected joint (patient- } \\
\text { reported or physician- } \\
\text { observed) } \\
\text { (ii) Can't bear touch or } \\
\text { pressure to affected joint } \\
\text { (iii) Great difficulty with } \\
\text { walking or inability to use } \\
\text { affected joint }\end{array}$} & No characteristics \\
\hline & & One characteristic \\
\hline & & Two characteristics \\
\hline & & Three characteristics \\
\hline & \multirow{3}{*}{$\begin{array}{l}\text { Time-course of episode(s) } \\
\text { ever: } \\
\text { Presence (ever), irrespective } \\
\text { of anti-inflammatory } \\
\text { treatment: } \\
\text { (i) Time to maximal pain } \\
<24 \mathrm{~h} \\
\text { (ii) Resolution of symptoms } \\
\text { in } \leq 14 \text { days } \\
\text { (iii) Complete resolution } \\
\text { (to baseline level) between } \\
\text { symptomatic episodes }\end{array}$} & No typical episodes \\
\hline & & One typical episode \\
\hline & & Recurrent typical episodes \\
\hline & \multirow{2}{*}{$\begin{array}{l}\text { Clinical evidence of tophus: } \\
\text { Draining or chalk-like } \\
\text { subcutaneous nodule under } \\
\text { transparent skin, often with } \\
\text { overlying vascularity, located } \\
\text { intypical locations: joints, } \\
\text { ears, olecranon bursae, finger } \\
\text { pads, tendons (e.g. Achilles) }\end{array}$} & Absent \\
\hline & & Present \\
\hline
\end{tabular}

\section{Colchicine:}

Colchicine may be used (within 12 hours of flare onset) at a loading dose of $1 \mathrm{mg}$ followed by $0.5 \mathrm{mg}$ an hour later on day 1 and/or colchicine tablets of $0.5 \mathrm{mg} \mathrm{BD} / \mathrm{TDS}$.

Use colchicine with caution in patients with severe renal or liver impairment.

Drug interactions between colchicine and strong P-glycoprotein and/or CYP3A4 inhibitors such as cyclosporin or clarithromycin and simvastatin may mean that it is safer to avoid colchicine.

In patients with frequent flares and contraindications to colchicine, use NSAIDs or corticosteroid (oral and injectable).

Combination therapy, such as colchicine and NSAID or colchicine and corticosteroids, can be prescribed for patients with particularly severe acute gout.

IL-1 blockers are prohibitively expensive and rarely used for treating prolonged refractory flares in the tertiary care setting. Acute infection is a contraindication to their use.

\section{COX1 and COX2 inhibitors:}

Avoid using in patients with renal impairment CKD 3 and active peptic ulcer disease.

Caution is needed in patients with known cardiovascular disease as an increased risk of myocardial infarction, stroke and heart failure has been associated with these drugs although whether such risk is increased in patients receiving short courses of NSAID for a gout flare is unknown.

There is no preference of one over other NSAIDs. Common NSAIDs (COX-1), indomethacin 50mg TDS, naproxen $550 \mathrm{mg}$ $\mathrm{BD}$ and diclofenac sodium 50mg TDS or / (COX-2) Etoricoxib 90 or $120 \mathrm{mg}$ OM (maximum for a week) can be used.

Total duration of NSAID therapy for a gout flare is five to seven days.

\section{Corticosteroids:}

Oral corticosteroids may be used, especially in patients with renal impairment or drug allergies. Use prednisolone $30-35 \mathrm{mg}$ /day for 3-5 days.

\section{General advice:}

1. Adequate hydration and rest

2. Removal of medication triggers e.g. diuretics

3. Avoid high purine foods, sugar sweetened drinks and alcohol(beer)

4. Apply ice packs 


\section{Reference}

1. Richette P, Doherty M, Pascual E, Barskova V, Becce F, Castaneda-Sanabria J, Coyfish M, Guillo S, Jansen TL, Janssens H, Lioté F. 2016 updated EULAR evidence-based recommendations for the management of gout. Annals of the rheumatic diseases. 2017 Jan $1 ; 76(1): 29-42$.

2. Neogi T, Jansen TL, Dalbeth N, Fransen J, Schumacher HR, Berendsen D, Brown M, Choi H, Edwards NL, Janssens HJ, Lioté F. 2015 gout classification criteria: an American College of Rheumatology/European League Against Rheumatism collaborative initiative. Arthritis \& rheumatology. 2015 Oct;67(10):2557-68.

3. Teng GG, Ang LW, Saag KG, Mimi CY, Yuan JM, Koh WP. Mortality due to coronary heart disease and kidney disease among middle-aged and elderly men and women with gout in the Singapore Chinese Health Study. Annals of the rheumatic diseases. 2012 Jun $1 ; 71(6): 924-8$.

4. Pascual E, Sivera F. Time required for disappearance of urate crystals from synovial fluid after successful hypouricaemic treatment relates to the duration of gout. Annals of the rheumatic diseases. 2007 Aug 1;66(8):1056-8.
5. Paganoni S, Schwarzschild MA. Urate as a marker of risk and progression of neurodegenerative disease. Neurotherapeutics. 2017 Jan 1;14(1):148-53.

6. G Cutler R, Camandola S, F Malott K, A Edelhauser M, P Mattson M. The role of uric acid and methyl derivatives in the prevention of age-related neurodegenerative disorders. Current topics in medicinal chemistry. 2015 Nov 1;15(21):2233-8.

7. Perez-Ruiz F, Lioté F. Lowering serum uric acid levels: what is the optimal target for improving clinical outcomes in gout? Arthritis Care \& Research. 2007 Oct 15;57(7):1324-8.

8. Khanna D, Fitzgerald JD, Khanna PP, Bae S, Singh MK, Neogi T, Pillinger MH, Merill J. Lee S, Prakash S, Kaldas M. 2012 American College of Rheumatology guidelines for management of gout. Part 1: systematic nonpharmacologic and pharmacologic therapeutic approaches to hyperuricemia. Arthritis care \& research. 2012 Oct 1;64(10):1431-46.

9. Khanna D, Khanna PP, Fitzgerald JD, Singh MK, Bae S, Neogi T, Pillinger MH, Merill J, Lee S, Prakash S, Kaldas M. 2012 American College of Rheumatology guidelines for management of gout. Part 2: therapy and anti-inflammatory prophylaxis of acute gouty arthritis. Arthritis care \& research. 2012 Oct;64(10):1447-61.

\section{LEARNING POINTS}

- ULT is indicated in patients with recurrent flare >2 times per year, tophi, urate arthropathy and/or presence of renal stones.

- While different xanthine oxidase inhibitors and uricosuric agents can be used, the indication for starting medication, action plan and side effects must be explained to the patient.

- Prophylaxis (colchicine or low dose oral corticosteroids for those who cannot take colchicine) should be commenced during the early months of ULT to reduce the risk of additional flares, which are common early in the course of ULT.Allopurinol should be continued during acute attacks for patients already on this. 